\begin{tabular}{|l|l|l||}
\hline \multicolumn{2}{|c|}{ PublisherInfo } \\
\hline \hline PublisherName & $:$ & BioMed Central \\
\hline \hline PublisherLocation & $:$ & London \\
\hline \hline PublisherImprintName & $:$ & BioMed Central \\
\hline \hline
\end{tabular}

\title{
Mutual interaction between breast epithelial and fibroblast cells
}

\begin{tabular}{|c|c|c|}
\hline \multicolumn{3}{|c|}{ ArticleInfo } \\
\hline ArticleID & : & 3655 \\
\hline ArticleDOI & : & $10.1186 /$ bcr-1999-66633 \\
\hline ArticleCitationID & : & 66633 \\
\hline ArticleSequenceNumber & : & 21 \\
\hline ArticleCategory & : & Paper Report \\
\hline ArticleFirstPage & : & 1 \\
\hline ArticleLastPage & : & 4 \\
\hline ArticleHistory & : & $\begin{array}{lll}\text { RegistrationDate } & : 1999-10-14 \\
\text { OnlineDate } & : 1999-10-14\end{array}$ \\
\hline ArticleCopyright & : & Current Science Ltd1999 \\
\hline ArticleGrants & : & \\
\hline ArticleContext & : & 1305822 \\
\hline
\end{tabular}




\section{Keywords}

epithelial, fibroblast, HGF, mammary, prostaglandin

\section{Introduction}

Epithelial-stromal interactions are known to be important in both normal breast development and neoplasia. However, little is known about the specific mediator molecules involved in these paracrine events. Mesenchymal-derived hepatocyte growth factor (HGF) has been shown to be mitogenic, motogenic and morphogenic in a variety of tissues including the breast, where it activates the Met receptor on epithelial cells. Mutual interactions between carcinoma cells and fibroblasts may lead to increased production and release of this growth factor.

\section{Aims}

To identify mammary carcinoma cell-derived factors that induce HGF expression in breast fibroblasts.

\section{Comments}

Epithelial-stromal interactions are very complex and this paper goes some way in identifying two of the specific mediators involved. The authors use a variety of well-controlled methods and discuss their results in the context of the clinical situation. In vitrohuman breast epithelial cell studies are now needed to confirm these results.

\section{Methods}

A range of concentrations of HGF was added to mouse mammary carcinoma cells (MMT cell line) and their growth (cell counts) and motility (scattering) measured in culture. Epithelial cell invasion 
through a basement membrane matrix (Matrigel) using invasion chambers in the presence of HGF or normal human dermal fibroblasts with/without pre-immune IgG, anti-human HGF $(10 \mu \mathrm{g} / \mathrm{ml})$, indomethacin $\left(10^{-7} \mathrm{M}\right)$, or indomethacin $\left(10^{-7} \mathrm{M}\right)$ plus prostaglandin E2 (PGE2), was also assessed. HGF released from normal skin or tumour cell associated primary human breast fibroblasts, and PGE2secreted from epithelial cells (MMT) was measured by ELISA. MMT cell-derived HGF-inducing factor was purified from lyophilised conditioned medium (CM) using Sephadex G-25 columns and reverse phase (RP) HPLC. Zymography for gelatinase and urokinase-type plasminogen activator (u-PA) was used to identify proteases released from carcinoma cells.

\section{Results}

Addition of 25 and 50\% MMT cell-derived CM for $24 \mathrm{~h}$ stimulated a 4-5 fold increase in the release of HGF from normal human dermal fibroblasts in culture. Treatment with specific antibodies and antagonists showed that this effect was not due to PDGF, FGF2, IL-1 and TGF $\alpha$, all of which have been shown to be released from carcinoma cells.

MMT CM was concentrated and purified by RP HPLC, and HGF production by fibroblasts was used as the assay for the inducing factor. PGE2 not only stimulated the production of HGF by cultured fibroblasts but also co-eluted with the peak of HGF-inducing activity in MMT CM. Both the HPLC peak and its activity were eliminated in the presence of the specific cyclo-oxygenase inhibitor, indomethacin, in a dose-dependent manner as was the secretion of PGE2 from the MMT cells. No consistent differences were found between the amount of HGF released from normal dermal fibroblasts and those found associated with human breast tumour cells, although both PGE2 and MMT CM could stimulate an increase in HGF release from both cell types.

HGF stimulated both the growth, motility and Matrigel invasion of the MMT cells. In co-culture invasion assays, normal human dermal fibroblasts seeded in the lower compartment of an invasion chamber stimulated the invasion of epithelial cells from the upper compartment through a layer of Matrigel. Similarly, the level of HGF produced by the fibroblasts was increased in the presence of MMT cells. Both activities were inhibited by indomethacin and an antibody to HGF. The simultaneous addition of $10^{-6} \mathrm{M} \mathrm{PGE}_{2}$ reversed the inhibition by indomethacin.

HGF treatment also increased the release of u-PA protease, but not gelatinase activity from MMT cells.

\section{Discussion}

Breast fibroblast-derived HGF has previously been shown to be important in branching morphogenesis of the human mammary gland, as well as being mitogenic, motogenic and morphogenic 
for a variety of epithelial cell types. It is therefore conceivable that the paracrine action of HGF from the host mesenchyme could be involved in the proliferation and spread of breast cancer cells.

Results presented in this paper not only show that HGF is a potent growth and motility factor for MMT mouse mammary carcinoma cells, but also demonstrates that the carcinoma cells themselves produce an HGF-inducing factor. MMT cell-derived PGE2 stimulated the release of HGF from both normal dermal fibroblasts and those associated with human breast tumour cells, suggesting that there is a mutual interaction between these cell types. HGF also increased protease release from the mouse carcinoma cells which correlated with their increased invasiveness through the Matrigel.

Both $\mathrm{PGE}_{2}$ and HGF have been shown to be elevated in human breast tumours and HGF levels are a strong indicator of tumour recurrence. Interestingly, non-steroidal anti-inflammatory drugs which inhibit cyclo-oxygenase activity and therefore PG production reduce the incidence of a variety of cancers, including breast.

\section{References}

1. Matsumoto-Taniura N, Matsumoto K, Nakumura T: Prostaglandin production in mouse mammary tumour cells confers invasive growth potential by inducing hepatocyte growth factor in stromal fibroblasts. Br J Cancer. 1999, 81: 194-202. 